\title{
Carcass composition and body fat depots of Galego Bragançano and crossbred lambs by Suffolk and Merino Precoce sire breeds
}

\author{
A. Teixeira ${ }^{1}$, R. Delfa ${ }^{2}$ and T. Treacher ${ }^{3}$ \\ ${ }^{1}$ Escola Superior Agrária, Instituto Politécnico de Bragança, Área de Zootecnia, Apartado 172, 5300 Bragança, Portugal \\ 'Unidad de Tecnologia en Producción Animal, Servicio de Investigación Agrária, Diputación General de Aragon, \\ Apartado 727, 50080 Zaragoza, Spain \\ ${ }^{3}$ Departamento de Producción Animal, Universidad de Córdoba, ETSIAM, Apartado 3948, 14080 Córdoba, Spain
}

\begin{abstract}
The main purpose of this work was to compare two breeds of improved rams (Suffolk and Merino Precoce) with the local Galego Bragançano breed for the production of crossbred slaughter lambs and to evaluate which cross was more adapted for meat production from the local breed in locations in the north-east of Portugal. The experiment was carried out over a 4-year period in three locations: (1) a farm with an intensive management; (2) an upland farm (400 to $600 \mathrm{~m}$ ); and (3) a hill farm (above $800 \mathrm{~m}$ ). Within each flock with 90 Galego Bragançano ewes, two rams of each of the sire breeds were used: Galego Bragançano, Suffolk and Merino Precoce. The lambs were slaughtered at 20 and $40 \mathrm{~kg}$, to obtain the carcass weight range of 8 to $14 \mathrm{~kg}$. The left sides of 151 carcasses were dissected into muscle, subcutaneous fat, intermuscular fat and bone. The lambs from location 1 had the highest carcass muscle proportion and the lowest carcass intermuscular fat proportion; their differences over locations 2 and 3 were 13 and $16 \mathrm{~g} / \mathrm{kg}$ for muscle proportion and 11 and $19 \mathrm{~g} / \mathrm{kg}$ for intermuscular fat proportion, respectively. The differences between breeds were relatively small and not significant. However the Suffolk crosses had less kidney, knob and channel fat than the other genotypes (5 and $12 \mathrm{~g} / \mathrm{kg}$ less than Merino crosses and Bragançano, respectively). The Suffolk crosses tended to have less body fat.
\end{abstract}

Keywords: body fat, carcass composition, crossbreeding lambs, farm comparisons, lambs.

\section{Introduction}

Crossbreeding for meat production in sheep has a long tradition and is very widely used. The effects of breed type, geographical origin and sampling time on the most important carcass characteristics of the main types of British lamb was carried out by Kempster and Cuthbertson (1977). A comparison of eight sire breeds for lamb production was carried out over a period of 8 years by More O'Ferrall and Timon (1977a and b). However, the information on carcass composition was based on the dissection of the best neck sample joint and according to Kempster (1981) the relationship between the composition of this joint and the carcass compositions differs significantly between breeds. Information on the carcass characteristics and the importance of stage of maturity of Clun, Colbred,
Hampshire Down and Suffolk lambs has been reported by Wood et al. (1980). Growth and carcass composition in the crossbred progeny of six terminal sire breeds (Dorset Down, Oxford Down, Suffolk, Ile de France, Oldenburg and Texel) were analysed by Wolf et al. (1980). Cameron and Drury (1985) have extended the range of breeds to include two more from France (Charollais and Charmoise), a synthetic breed (Meatlinc) in addition to the Texel, Oxford and the Texel-Oxford cross.

According to Kempster et al. (1987) the key factor in an improvement scheme of sheep production is the matching of breed and production system to obtain lean carcasses at an optimum slaughter weight and age. Kempster et al. (1987) and Croston et al. (1987) reported relevant information from an experiment 
Table 1 Lamb distribution according to sire breed, sex and location

\begin{tabular}{|c|c|c|c|c|c|c|c|}
\hline & \multicolumn{6}{|c|}{ Sire breed } & \multirow[b]{3}{*}{ Total } \\
\hline & \multicolumn{2}{|c|}{ Bragançano } & \multicolumn{2}{|c|}{ Suffolk } & \multicolumn{2}{|c|}{ Merino } & \\
\hline & Males & Females & Males & Females & Males & Females & \\
\hline \multicolumn{8}{|c|}{ Location } \\
\hline 1 & 14 & 3 & 8 & 5 & 8 & 10 & 48 \\
\hline 2 & 6 & 7 & 6 & 6 & 6 & 6 & 37 \\
\hline 3 & 40 & 9 & 2 & 1 & 9 & 5 & 66 \\
\hline Total & 60 & 19 & 16 & 12 & 23 & 21 & 151 \\
\hline
\end{tabular}

involving 10 sire breeds and carried out in commercial flocks covering a range of geographical regions and different production systems.

Constraints on changes in lamb production in Portugal are imposed by the existing structure of sheep farming in the country with a strong priority for milk production and by the traditional consumer preferences for lamb meat. According to Teixeira and Delfa (1993) consumption in Portugal is mainly of fresh, light-weight carcasses from young lambs with coloured meat and little fat. A great part of lamb consumption in Portugal is provided by suckled lambs (Borrego de canastra) weaned at 5 to 7 weeks to provide a long milking period for the ewes. The carcass weight is 6 to $10 \mathrm{~kg}$. This type of lamb is preferred particularly during the Christmas, Carnival and Easter periods, when there is a high demand. Other commercial categories are: Borrego corrente, lambs slaughtered at 5 to 6 months old, with carcass weight not exceeding $10 \mathrm{~kg}$; and Ovino adulto, adult animals of variable age and carcass weight.

There is little information on the production of lambs or the value of crossbreeding in the different environments of north-eastern Portugal. A programme of research was designed therefore to compare two breeds of improved rams, the Suffolk and the Merino Precoce, with the local Galego Bragançano for production of lambs for slaughter from local Galego Bragançano ewes and assess if there were differences in the adaptation of the genotypes to the different environmental conditions in the north-east of Portugal, particularly the harsh conditions of the mountains of the Montesinho Natural Park.

Suffolk and Merino Precoce, together with the Ile de France, are the most important breeds used for crossbreeding in Portugal. The Suffolk breed was introduced to the north-east of Portugal in 1984, when two males and one female were presented by the United Kingdom ambassador to the Polytechnic
Institute of Bragança. Two years later a further 15 females and 10 males were imported from the Suffolk Sheep Society in the United Kingdom. The Merino Precoce rams for the experiment were bought from a member of the Portuguese Merino Precoce Breeders Association in the south of Portugal.

\section{Material and methods}

The experiment was carried out over a 4-year period in flocks of Galego Bragançano ewes on farms in three locations, selected to cover a range of management and climatic conditions of the northeast of Portugal. (1) The farm of Escola Superior Agrária de Bragança has intensive management, producing lambs off grass, conserved forages and finished on commercial concentrates. The commercial concentrate used had the following composition (g/kg): crude protein 160, crude cellulose 90, ash 100, crude fat 40, and was offered ad libitum and distributed daily. The pastures consisted mainly of subterranean clover of varieties Woogenellup, Mount Barker, Bachus Marsh and Clare and perennial rye-grass (variety Victorian). (2) The upland farm at 400 to $600 \mathrm{~m}$ in Montesinho Natural Park area, produces lambs off grass, some conserved forages and meadow hay, with a major period, in which stubbles are grazed. (3) The hill farm at above $800 \mathrm{~m}$ is located in Montesinho Natural Park, which is one of the largest protected areas in Portugal. The Park covers 75000 ha at an altitude varying from 438 to $1481 \mathrm{~m}$, in a succession of uplands and deep valleys. There are extensive areas of hill grazing, the weather is often harsh and there are wide variations in food supply. The flocks are rarely given supplementary foods. Frequently, in summer, the flocks graze in oak areas of Quercus pyrenaica forest.

\section{Flocks and animals}

In each flock, two rams of each of the sire breeds, Galego Bragançano, Suffolk and Merino Precoce, were used. The groups of six rams remained on the same farms throughout the 4 years of the 
Table 2 Mean lamb growth rates according to breed and location

\begin{tabular}{lcc}
\hline \hline & No. of lambs & $\begin{array}{c}\text { Daily gain } \\
\text { (g/day) }\end{array}$ \\
\hline $\begin{array}{l}\text { Sire breed } \\
\text { Bragançano }\end{array}$ & 79 & $190^{\mathrm{a}}$ \\
Suffolk & 28 & $262^{\mathrm{b}}$ \\
Merino & 44 & $245^{\mathrm{b}}$ \\
Location & 48 & $277^{\mathrm{c}}$ \\
1 & 37 & $212^{\mathrm{d}}$ \\
2 & 66 & $198^{\mathrm{d}}$ \\
3 & & $*$ \\
Significance of effectst & & $*$ \\
Breed & & \\
Location & & \\
\hline \hline
\end{tabular}

$a, b, c, d$ Means with the same superscript within the same column did not differ significantly $(P>0.05)$.

+ Sex, breed $X$ location and breed $X$ sex effects were not significant $(P>0.05)$.

experiment. Ninety ewes from each flock were separated at random into three groups of 30 ewes for mating with the pairs of rams from each breed for a period of 30 days. The distribution of lambs according to sire breed, sex and locations is given in Table 1 .

The lambs by all sire breeds were reared under the normal conditions of each farm. All lambs born on each farm were identified and weighed every 21 days, after the birth of the first lamb in each flock.

\section{Slaughter procedure, carcass evaluation and dissections}

At weaning, twin lambs of the same sex were assigned at random to two groups for slaughter to obtain the carcass weight range of 8 to $14 \mathrm{~kg}$ that covers the main requirements for lamb consumption in Portugal.

All lambs were slaughtered after a 24 -h fast in the experimental slaughter-house at the Escola Superior Agrária de Bragança. After slaughter, contents were removed from the digestive tract, weighed and subtracted from body weight before slaughter to obtain empty body weight. Omental, mesenteric, kidney knob and channel fat (KKCF - the perinephric and retroperitoneal fat) were removed and weighed separately. Carcasses were cooled at $6^{\circ} \mathrm{C}$ for $24 \mathrm{~h}$. Carcasses were halved carefully and the left side of the carcass was divided into eight standardized commercial joints: legs, chump, loin, ribs, anterior ribs, shoulder, breast and neck. The jointing procedure was outlined by Teixeira (1984) according to the commercial jointing and cutting system of Estação Zootécnica Nacional - Fonte Boa (EZN-Portugal). Each joint was then dissected into muscle, subcutaneous fat, intermuscular fat, bone and remainder (major blood vessels, ligaments, tendons and thick connective tissue sheets associated with some muscles). In all 151 carcasses were evaluated and dissected.

\section{Statistical analysis}

The analysis was restricted to twin lambs reared as twins. A least-squares model was fitted to the data with main effects for breed, farm location and sex. The subcutaneous fat proportion (SFP) obtained by tissue separation was fitted as covariate (Croston et al., 1987).

\section{Results and discussion}

The mean lamb growth rates for the breeds and farms, during all periods of the trial are shown in Table 2. There were significant effects $(P<0.05)$ of breed, location and growth rate, but the effect of sex and the interactions between breed and location and between breed and sex were not significant $(P>0.05)$. Suffolk lambs had the highest growth rate, but it was not significantly different from that of the Merino Precoce lambs. Farm 1, with the most intensive system had the highest growth rate $(P<0 \cdot 05)$.

The means and the significance of effects of sire breed and farm location on the weight of body fat depots and the farm location means are shown in Table 3. Male lambs had lower proportions of the three fat depots than the females with means of 15.5

Table 3 Mean weights of mesenteric, omental and KKCF depots ( $\mathrm{g} / \mathrm{kg}$ empty body weights) for sire breeds and locations

\begin{tabular}{|c|c|c|c|c|}
\hline & \multirow{2}{*}{$\begin{array}{l}\text { No. } \\
\text { of lambs }\end{array}$} & \multicolumn{3}{|c|}{$\begin{array}{c}\text { Body fat depots } \\
\text { (g/kg empty body weight) }\end{array}$} \\
\hline & & Omental & Mesenteric & $\mathrm{KKCF}$ \\
\hline \multicolumn{5}{|l|}{ Sire breed } \\
\hline Bragançano & 79 & $21 \cdot 5^{a}$ & $15 \cdot 3^{\mathrm{a}}$ & $16 \cdot 1^{\mathrm{a}}$ \\
\hline Suffolk & 28 & $15 \cdot 7^{b}$ & $12 \cdot 5^{\mathrm{b}}$ & $11 \cdot 9^{\mathrm{b}}$ \\
\hline Merino & 44 & $19 \cdot 6^{\mathrm{a}}$ & $14 \cdot 3^{a}$ & $14 \cdot 3^{a b}$ \\
\hline \multicolumn{5}{|l|}{ Location } \\
\hline 1 & 48 & $17 \cdot 3^{a}$ & $13 \cdot 7^{\mathrm{a}}$ & $13 \cdot 2^{\mathrm{a}}$ \\
\hline 2 & 37 & $24 \cdot 2^{b}$ & $15 \cdot 1^{\mathrm{a}}$ & $16 \cdot 6^{\mathrm{b}}$ \\
\hline 3 & 66 & $19 \cdot 2^{\mathrm{a}}$ & $14 \cdot 7^{\mathrm{a}}$ & $14.9^{a b}$ \\
\hline Approx s.e. & & $0 \cdot 77$ & $0 \cdot 38$ & $0 \cdot 69$ \\
\hline \multicolumn{5}{|c|}{ Significance of effectst } \\
\hline Breed & & $* *$ & $* *$ & $* *$ \\
\hline Sex & & $* *$ & ** & $* *$ \\
\hline Location & & $* *$ & & $* *$ \\
\hline Breed $\times$ sex & & $* *$ & & \\
\hline
\end{tabular}

$a, b$ Means with the same superscript within the same column did not differ significantly $(P>0.05)$.

+ Breed $\times$ location effects were not significant $(P>0.05)$. 


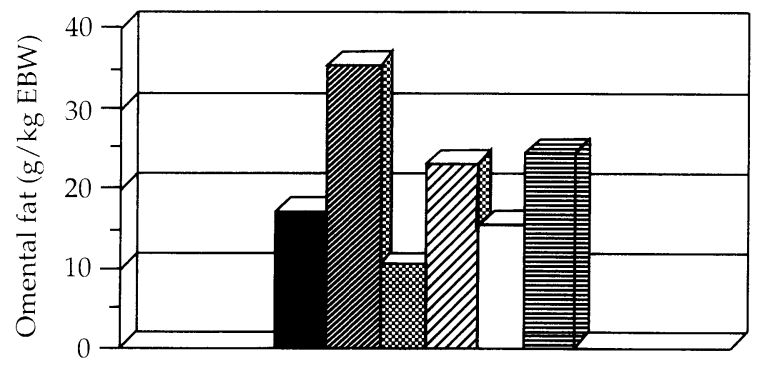

Figure 1 Omental fat (g/kg empty body weight (EBW)) proportion for breed $X$ sex interaction: $\mathbf{B}$ Bragançano males; $\mathbb{Z}$ Bragançano females; Suffolk males; $\boldsymbol{V}$ Suffolk females; $\square$ Merino males; $\boxminus$ Merino females.

v. $27.9 \mathrm{~g} / \mathrm{kg}$ for omental fat, 12.7 v. $17.8 \mathrm{~g} / \mathrm{kg}$ for mesenteric fat and $11.8 v .20 \cdot 1$ for $\mathrm{KKCF}$, for male and female lambs, respectively. The lambs from Suffolk crosses had less omental fat, mesenteric fat and $\mathrm{KKCF}$ than the others. Although the pure Bragançano lambs had the highest proportions of body fats, they were not significantly higher than in the Merino-cross lambs $(P>0 \cdot 05)$. The lambs from location 1 had the lowest omental fat and KKCF proportions $(P<0.01)$, but they were not significantly $(P>0.05)$ different from lambs from location 3. The highest proportion of body fat depots was recorded for lambs from farm location 2, but the mesenteric fat proportion did not differ significantly between locations $(P>0.05)$.

A significant breed $\times$ sex interaction $(P<0.01)$ was recorded for omental fat and is shown in Figure 1. Suffolk males were the lambs with lowest omental fat proportion (10.4 g/ $\mathrm{kg}$ empty body weight) and Bragançano females were the group with the highest omental fat proportion $(35.2 \mathrm{~g} / \mathrm{kg}$ empty body weight). Suffolk females did not differ significantly $(P>0.05)$ from Merino females.

The results from farm locations agree with the suggestion of Kempster (1980) that the ability of sheep to survive in hill environments is associated with greater fat deposition in the internal fat depots. Nevertheless the higher fatness in location 3 compared with locations 2 and 1 was related to the distribution of lambs (see Table 1) because location 3 had a greater proportion Bragançano lambs than the others, so the effect on the production system in this location could be lower.

Palsson (1940) reported that mountain breeds tend to accumulate more internal body fat than more specialized meat breeds. The purebred Brangançano had an internal body fat partition similar to mountain breeds. The results of this trial are consistent with those of Wood et al. (1980) who also reported that meat sire breeds, like Suffolk, had less

Table 4 Mean unadjusted proportion of subcutaneous fat and of other carcass tissues and ratios $(\mathrm{g} / \mathrm{kg})$ for sire breeds and locations after adjusted for weight of subcutaneous fatt

\begin{tabular}{|c|c|c|c|c|c|c|c|c|c|c|}
\hline & \multirow[b]{2}{*}{$\begin{array}{l}\text { No. of } \\
\text { lambs }\end{array}$} & \multirow[b]{2}{*}{$\begin{array}{c}\text { Subcutaneous } \\
\text { fatf }\end{array}$} & \multicolumn{5}{|c|}{ Tissue in carcass $(\mathrm{g} / \mathrm{kg})$} & \multicolumn{3}{|c|}{ Ratios } \\
\hline & & & Muscle & $\begin{array}{c}\text { Intermuscular } \\
\text { fat }\end{array}$ & $\begin{array}{l}\text { Total } \\
\text { fat }\end{array}$ & KKCF & Bone & $\begin{array}{l}\text { Muscle: } \\
\text { bone }\end{array}$ & $\begin{array}{l}\text { Muscle: } \\
\text { fat }\end{array}$ & $\begin{array}{l}\text { Subcut: } \\
\text { intermuscular }\end{array}$ \\
\hline \multicolumn{11}{|l|}{ Sire breed } \\
\hline Bragançano & 79 & $48^{\mathrm{a}}$ & $547^{a}$ & $164^{\mathrm{a}}$ & $245^{\mathrm{a}}$ & $32^{\mathrm{a}}$ & $152^{\mathrm{b}}$ & $3 \cdot 63^{a}$ & $2 \cdot 29$ & $0 \cdot 31$ \\
\hline Suffolk & 28 & $50^{a}$ & $555^{\mathrm{a}}$ & $168^{\mathrm{a}}$ & $238^{\mathrm{a}}$ & $20^{\mathrm{b}}$ & $160^{a}$ & $3 \cdot 47^{\mathrm{ab}}$ & $2 \cdot 46$ & 0.30 \\
\hline Merino & 44 & $57^{\mathrm{b}}$ & $557^{a}$ & $164^{\mathrm{a}}$ & $241^{\mathrm{a}}$ & $25^{c}$ & $157^{a}$ & $3.57^{b}$ & $2 \cdot 36$ & 0.32 \\
\hline \multicolumn{11}{|l|}{ Location } \\
\hline 1 & 48 & 51 & $563^{a}$ & $155^{\mathrm{a}}$ & $230^{\mathrm{a}}$ & $25^{a}$ & $155^{\mathrm{a}}$ & $3 \cdot 64^{a}$ & $2 \cdot 52^{\mathrm{a}}$ & $0.33^{a}$ \\
\hline 2 & 37 & 53 & $550^{\mathrm{b}}$ & $166^{\mathrm{b}}$ & $243^{b}$ & $27^{a}$ & $158^{a}$ & $3.49^{\mathrm{ab}}$ & $2 \cdot 31^{\mathrm{b}}$ & $0 \cdot 31^{\mathrm{b}}$ \\
\hline 3 & 66 & 49 & $547^{\mathrm{b}}$ & $174^{\mathrm{b}}$ & $251^{\mathrm{b}}$ & $25^{a}$ & $155^{\mathrm{a}}$ & $3.53^{b}$ & $2 \cdot 27^{\mathrm{b}}$ & $0 \cdot 30^{\mathrm{b}}$ \\
\hline Approx s.e. & & 10 & 30 & 20 & 32 & 19 & 9 & 0.025 & $0 \cdot 045$ & 0.007 \\
\hline \multicolumn{11}{|c|}{ Significance of effects $\S$} \\
\hline Breed & & ** & & & & $* *$ & $*$ & * & & \\
\hline Sex & & $* *$ & $* *$ & $* *$ & $* *$ & $* *$ & $* *$ & & $* *$ & * \\
\hline Location & & & * & $* *$ & $* *$ & $* *$ & & * & $* *$ & * \\
\hline Breed $\times$ location & & & ** & * & $* *$ & $* *$ & * & * & * & \\
\hline Breed $\times$ sex & & & $* *$ & $* *$ & $* *$ & $* *$ & $* *$ & & $* *$ & \\
\hline
\end{tabular}

a,b Means with the same superscript within the same column did not differ significantly $(P>0.05)$.

+ The subcutaneous fat proportion was fitted as covariate.

$\neq$ Without adjustment.

$\S$ Effect of breed $\times$ sex $\times$ location was not significant $(P>0.05)$. 
internal body fat than the breeds which were noted for prolificacy and milking ability which were termed 'ewe breeds'.

The means for carcass composition and the significance of effects of sire breed and farm location on carcass tissue proportions and ratios are shown in Table 4 . There were differences in the subcutaneous fat proportion. The Merino Precoce-cross carcasses had a significantly greater proportion of subcutaneous fat than the pure Bragançano and Suffolk-cross carcasses. This was the main reason for using the subcutaneous fat proportion (SFP) as a covariate. After covariance there were no differences between breeds in the proportion of intermuscular fat, total fat, muscle and the ratios between muscle and fat and between subcutaneous and intermuscular fat.

However, the Suffolk crosses had 5 and $12 \mathrm{~g} / \mathrm{kg}$ less $\mathrm{KKCF}$ than Merino crosses and Bragançano, respectively $(P<0.01)$. On the other hand the Bragançano had the lowest bone proportion resulting in a higher muscle : bone ratio. The muscle proportions of 547,555 and $557 \mathrm{~g} / \mathrm{kg}$ for Bragançano, Suffolk crosses and Merino crosses, respectively, are very similar to the results of Cameron and Drury (1985) and Croston et al. (1987).

The lambs from location 1 had the highest proportion of muscle $(P<0.05)$ and the lowest proportions of total fat and intermuscular fat $(P<0 \cdot 01)$. These differences were also reflected in ratios of muscle to fat and of subcutaneous to intermuscular fat, which were significantly greater for lambs from location 1 than for those from locations 2 and 3 , respectively.

There were significant effects of sex $(P<0 \cdot 01)$ on all parameters, except muscle : bone ratio. Males had a higher proportion of muscle $(566 \mathrm{v} .540 \mathrm{~g} / \mathrm{kg}$ ) and a lower proportion of total fat $(223 v .260 \mathrm{~g} / \mathrm{kg})$ than the females.

The means and the levels of significance of the interactions between breed and location for carcass tissue proportions and ratios are shown in Table 5 . The breed $\times$ location resulted from the relatively high muscle proportion of Merino crosses from locations 1 and 3 (573 and $555 \mathrm{~g} / \mathrm{kg}$, respectively) and the superiority of Suffolk crosses from location 2 $(561 \mathrm{~g} / \mathrm{kg})$.

The advantages of the Suffolk crosses reflected a higher, but not significantly different, muscle: fat ratio (2.46), which is higher than the values obtained by Croston et al. (1987) but similar to those of Wolf et al. (1980). Nevertheless the Bragançano had the highest muscle : bone ratio (3.63), which is similar to the values of 3.68 and 3.72 found in Texel crosses by Croston et al. (1987) and by Wolf et al. (1980), respectively.

Lambs reared in very different nutritional and climatic conditions, and differing significantly in growth rate (Table 2 ), showed very little difference in carcass characteristics. The lack of balance in the number of lambs from the three crosses in the different locations is a problem related to the difficulties of doing this type of work on commercial

Table 5 Mean carcass tissue proportionst $(\mathrm{g} / \mathrm{kg})$ and ratios for the three breeds at each location

\begin{tabular}{|c|c|c|c|c|c|c|c|}
\hline & \multicolumn{5}{|c|}{ Tissue in carcass $(\mathrm{g} / \mathrm{kg})$} & \multicolumn{2}{|c|}{ Ratios } \\
\hline & Muscle & Intermuscular fat & Total fat & $\mathrm{KKCF}$ & Bone & Muscle : bone & Muscle : fat \\
\hline \multicolumn{8}{|l|}{ Location 1} \\
\hline Bragançano & $553^{\mathrm{abc}}$ & $159^{\mathrm{abc}}$ & $241^{\text {ad }}$ & $33^{a}$ & $147^{a}$ & $3.78^{a}$ & $2 \cdot 35^{\mathrm{ac}}$ \\
\hline Suffolk & $563^{\mathrm{ac}}$ & $149^{a}$ & $219^{c}$ & $20^{\mathrm{b}}$ & $163^{c}$ & $3 \cdot 47^{\mathrm{b}}$ & $2 \cdot 66^{\mathrm{b}}$ \\
\hline Merino & $573^{c}$ & $155^{\mathrm{ab}}$ & $229^{\mathrm{abc}}$ & $21^{\mathrm{b}}$ & $157^{\mathrm{bc}}$ & $3 \cdot 67^{\mathrm{ab}}$ & $2 \cdot 55^{\mathrm{ab}}$ \\
\hline \multicolumn{8}{|l|}{ Location 2} \\
\hline Bragançano & $546^{\mathrm{ab}}$ & $160^{\mathrm{abc}}$ & $240^{\text {abd }}$ & $30^{\mathrm{a}}$ & $156^{\mathrm{bc}}$ & $3 \cdot 50^{\mathrm{b}}$ & $2 \cdot 29^{\mathrm{ac}}$ \\
\hline Suffolk & $561^{\mathrm{abc}}$ & $171^{\mathrm{c}}$ & $243^{\mathrm{abd}}$ & $22^{\mathrm{b}}$ & $161^{\mathrm{bc}}$ & $3 \cdot 50^{\mathrm{b}}$ & $2 \cdot 43^{\mathrm{ab}}$ \\
\hline Merino & $543^{\mathrm{ab}}$ & $167^{\mathrm{bc}}$ & $247^{\mathrm{abd}}$ & $29^{a}$ & $158^{\mathrm{bc}}$ & $3 \cdot 48^{\mathrm{b}}$ & $2 \cdot 22^{c}$ \\
\hline \multicolumn{8}{|l|}{ Location 3} \\
\hline Bragançano & $545^{\mathrm{b}}$ & $171^{\mathrm{c}}$ & $254^{\mathrm{d}}$ & $32^{\mathrm{a}}$ & $152^{\mathrm{ab}}$ & $3 \cdot 60^{\mathrm{ab}}$ & $2 \cdot 23^{c}$ \\
\hline Suffolk & $541^{\mathrm{ab}}$ & $183^{c}$ & $252^{\mathrm{abd}}$ & $17^{\mathrm{b}}$ & $158^{\mathrm{bc}}$ & $3 \cdot 42^{\mathrm{b}}$ & $2 \cdot 29^{\mathrm{ac}}$ \\
\hline Merino & $555^{\mathrm{abc}}$ & $169^{c}$ & $247^{\text {abd }}$ & $25^{\mathrm{b}}$ & $156^{\mathrm{bc}}$ & $3 \cdot 57^{\mathrm{ab}}$ & $2 \cdot 30^{\mathrm{ac}}$ \\
\hline
\end{tabular}

$\mathrm{a}, \mathrm{b}, \mathrm{c}, \mathrm{d}$ Means with the same superscript within the same column did not differ significantly $(P>0 \cdot 05)$.

+ Subcutaneous fat proportion was fitted as covariate. 
farms in contrast with work where carcass data have been obtained for lambs from research farm systems.

In conclusion, the superiority of Suffolk and Merino crosses, in location 1 , indicates the possibility of using these sires breeds under a fairly intensive management system. Purebred Bragançano lambs had a fat partition similar to the Clun Forest and Colbred breeds which were termed ewe breeds by Wood et al. (1980) and seem to be more adapted to the harsher environment conditions of the Montesinho Park.

Globally the results indicate the strength of the local breed, in terms of carcass fat content and muscle: bone ratio in a situation, as in Portugal, where the market and the meat trade does not set a premium on good conformation, which is negatively associated with fat content. Therefore, there is no strong pressure to crossbreed for improved carcass conformation. However, depending on the effects of farm location on growth rate, or any interactions in these characteristics with breed, there may be a value in crossbreeding to reduce the age at which lambs can be slaughtered in better environments.

\section{Acknowledgements}

This research was supported by grants from the Instituto Politécnico de Bragança. The authors wish to acknowledge the help given by Dr A. J. Kempster in the early design of the project. Thanks are due to staff at Escola Superior Agrária de Bragança and to Cooperative Agrícola de Montesinho, for carcass dissections and the selection of farm locations, respectively.

\section{References}

Cameron, N. D. and Drury, D. J. 1985. Comparison of terminal sire breeds for growth and carcass traits in crossbred lambs. Animal Production 40: 315-322.

Croston, D., Kempster, A. J., Guy, D. R. and Jones, D. W. 1987. Carcass composition of crossbred lambs by ten sire breeds compared at the same carcass subcutaneous fat proportion. Animal Production 44: 99-106.
Kempster, A. J. 1980. Fat partition and distribution in the carcasses of cattle, sheep and pigs: a review. Meat Science 5: 83-98.

Kempster, A. J. 1981. The indirect evaluation of sheep carcass composition in breeding schemes, population studies and experiments. Livestock Production Science 8: 263-271.

Kempster, A. J., Croston, D., Guy, D. R. and Jones, D. W. 1987. Growth and carcass characteristics of crossbred lambs by ten sire breeds, compared at the same estimated carcass subcutaneous fat proportion. Animal Production 44: 83-98.

Kempster, A. J. and Cuthbertson, A. 1977. A survey of the carcass characteristics of the main types of British lamb. Animal Production 25: 165-180.

More O'Ferrall, G. J. and Timon, V. M. 1977a. A comparison of eight sire breeds for lamb production. 1. Lamb growth and carcass measurements. Irish Journal of Agricultural Research 16: 267-275.

More O'Ferrall, G. J. and Timon, V. M. 1977b. A comparison of eight sire breeds for lamb production. 2. Lamb carcass composition. Irish Journal of Agricultural Research 16: 277-284.

Palsson, H. 1940. Meat qualities in the sheep with special reference to Scottish breeds and crosses. III. Comparative development of selected individuals of different breeds and crosses as lambs and hoggets. Journal of Agricultural Science, Cambridge 30: 1-82.

Teixeira, A. 1984. Avaliação das carcaças de borregos do grupo étnico Churro Galego Bragançano e seu cruzamento com a raça Milchschaf. [Lamb carcass evaluation of Galego Bragançano and its cross with Milchschaf breed]. Relatório de estágio do curso de Engenharia Zootécnica da UTAD - Vila Real.

Teixeira, A. and Delfa, R. 1993. Sheep consumer preferences and commercial classification in the mediterranean area of the european community. Proceedings of the 44th annual meeting of the European Association for Animal Production, Aarhus, vol. II, pp. 134-135 (abstr.).

Wolf, B. T., Smith, C. and Sales, D. I. 1980. Growth and carcass composition in the crossbred progeny of six terminal sire breeds of sheep. Animal Production 31: 307-313.

Wood, J. D., MacFie, H. J. H., Pomeroy, R. W. and Twinn, D. J. 1980. Carcass composition in four sheep breeds: the importance of type of breed and stage of maturity. Animal Production 30: 135-152.

(Received 20 August 1995-Accepted 15 June 1996) 